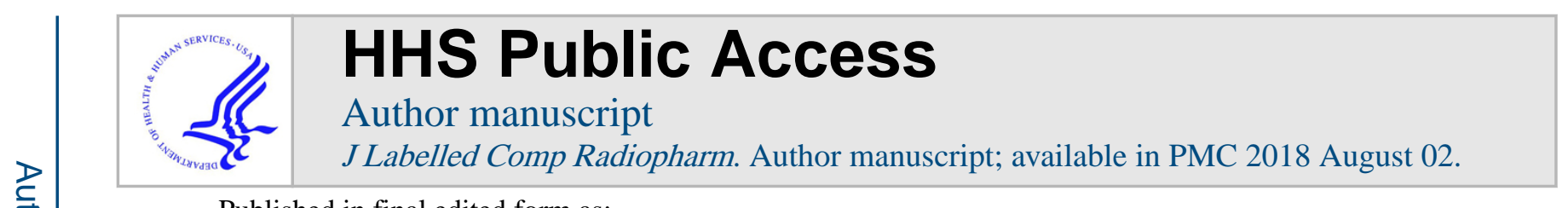

Published in final edited form as:

J Labelled Comp Radiopharm. 2017 August ; 60(10): 460-465. doi:10.1002/jlcr.3521.

\title{
Synthesis of S-2-((S)-3-(4-chlorophenyl)- $N^{\prime}-((4-$ chlorophenyl)sulfonyl)-4-phenyl-4,5-dihydro-1 H-pyrazole-1- carboximidamido)-3-(methyl- $d_{3}$ )butanamide- $d_{5}$, octa-deuterated JD5037
}

\author{
Malliga R. Iyer ${ }^{1}$, Resat Cinar ${ }^{1}$, Nathan J. Coffey ${ }^{1}$, Robert J. Chorvat ${ }^{2}$, and George Kunos ${ }^{1}$ \\ ${ }^{1}$ Laboratory of Physiologic Studies and National Institute on Alcohol Abuse and Alcoholism, \\ National Institutes of Health, 5625 Fishers Lane, Rockville, MD 20852, USA \\ 2Jenrin Discovery LLC, 285 Wilmington-West Chester, Chadds Ford, PA 19317, USA
}

\begin{abstract}
JD5037 (1) is a potent and selective, peripherally acting inverse agonist of the cannabinoid $\left(\mathrm{CB}_{1} \mathrm{R}\right)$ receptor. Peripheral $\mathrm{CB}_{1}$ receptor antagonists/inverse agonists have great potential in the treatment of metabolic disorders like type 2 diabetes, obesity and NASH. We report the synthesis of octadeuterated $\left[{ }^{2} \mathrm{H}_{8}\right]-J D 5037(S, S)(\mathbf{8})$ along with its $(S, R)$ diastereomer $(\mathbf{1 3})$ from commercially available L-valine-d 8 starting material. The $\left[{ }^{2} \mathrm{H}_{8}\right]-J D 5037$ compound will be used to quantitate unlabeled JD5037 during clinical ADME studies and will be used as an LC-MS/MS bioanalytical standard.
\end{abstract}

\section{TOC image}

We report the synthesis of octa-deuterated $\left[{ }^{2} \mathrm{H}_{8}\right]-J D 5037(S, S)(8)$ along with its $(S, R)$ diastereomer (13) from commercially available L-valine-D8 starting material. The ${ }^{2} \mathrm{H}_{8}$-JD5037 compound will be used to quantitate unlabeled JD5037 during clinical ADME studies and will be used as an LC-MS/MS bioanalytical standard. 


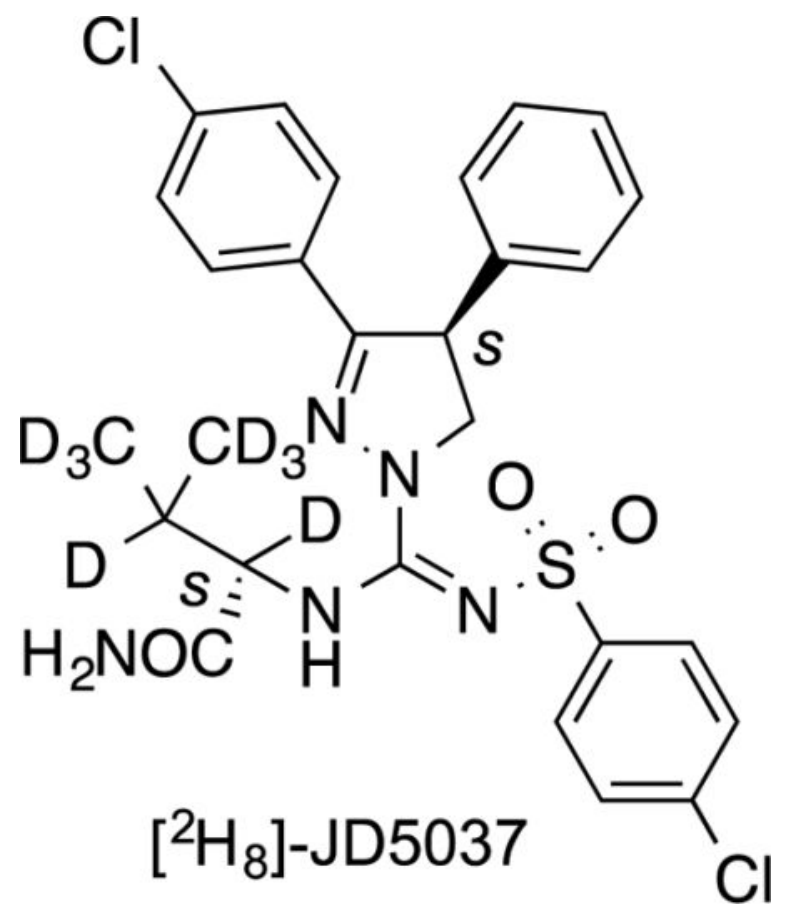

\section{Keywords}

$\mathrm{EC} ; \mathrm{CB}_{1} \mathrm{R} ; \mathrm{PSA} ; \mathrm{ADME}$

\section{Introduction}

Endocannabinoids (EC) are endogenous ligands found throughout the body where they bind to two known cannabinoid receptors, $\mathrm{CB}_{1}$ and $\mathrm{CB}_{2}{ }^{1}$. These endogenous ligands, their two G-protein coupled receptors along with several enzymes responsible for their biosynthesis and degradation constitute the endocannabinoid system ${ }^{2,3}$. The $\mathrm{CB}_{1}$ receptor $\left(\mathrm{CB}_{1} \mathrm{R}\right)$ is mainly expressed in the central nervous system, where it is one of the most abundant GPCRs. It is also expressed in a number of peripheral tissues such as the liver, testis and ileum. ${ }^{4}$ The $\mathrm{CB}_{2}$ receptor is mainly expressed by cells of the immune system, and is involved in the immunomodulatory effects of cannabinoids ${ }^{5}$. The $\mathrm{CB}_{1} \mathrm{R}$ gained attention due to its role in regulating appetite and food intake ${ }^{6}$. The modulation of endocannabinoid functions through $\mathrm{CB}_{1} \mathrm{R}$ antagonism has been recognized as a viable therapeutic strategy to treat obesity and its associated metabolic complications ${ }^{7}$. The first-in-class and only $\mathrm{CB}_{1} \mathrm{R}$ antagonist to be approved as an anti-obesity medication, rimonabant (2), was withdrawn from the market soon after its approval in Europe due to the occurrence of neuropsychiatric side effects including depression, anxiety and suicidal ideation. Clinical development of similar brain-penetrant agents, such as ibipinabant (3), otenabant (4) and taranabant (5) ${ }^{8}$ was also terminated. While it was initially thought that the beneficial effects of $\mathrm{CB}_{1} \mathrm{R}$ antagonism could not be separated from neuropsychiatric side effects resulting from brain $\mathrm{CB}_{1} \mathrm{R}$ occupancy, a new body of evidence suggests that most of the beneficial effects can be retained by sequestering the agents away from the brain and limiting their access to the 
periphery. ${ }^{9}$ This justified a 're-do' of the $\mathrm{CB}_{1} \mathrm{R}$ antagonism strategy by developing non-brain penetrant versions of compounds, which are in early development ${ }^{10}$.

Strategies for designing non-brain penetrant compounds are well documented. ${ }^{11}$ Thus, in case of $\mathrm{CB}_{1} \mathrm{R}$, agents with low propensity to penetrate the $\mathrm{BBB}$ were designed by utilizing the conventional functionalities that offer an increase in polar surface areas. Molecules with a PSA of $>120$ have poor passive cell membrane permeability indicating low oral bioavailability. ${ }^{12}$ For compounds with limited brain penetrance, PSA is generally found to be in the range of $80-120$.

One of the first compounds with peripherally selective $\mathrm{CB}_{1} \mathrm{R}$ profile was TM38837 (6) (structure undisclosed) identified by 7TM Pharma. This compound was tested in a small number of healthy subjects at a dose predicted to be equipotent with rimonabant without eliciting adverse effects; however, limited data is available regarding its structure, in vitro and physiochemical properties ${ }^{13}$. Earlier efforts to develop peripherally-restricted $\mathrm{CB}_{1} \mathrm{R}$ antagonists focused on the rimonabant scaffold, the team at Jenrin Discovery used the ibipinabant template as a starting point to develop non-brain penetrant $\mathrm{CB}_{1} \mathrm{R}$ antagonists. The compounds advanced by this group include JD5037 (1) and JD5006 (7). ${ }^{14}$ Replacement with pendant $\mathrm{N}$-L-valinamide in lieu of $\mathrm{N}$-methyl group in case of ibipinabant was found to be particularly attractive because it resulted in excellent $\mathrm{CB}_{1} \mathrm{R}$ affinity, favorable physicochemical parameters as well as peripheral restriction. JD5037 has been extensively studied in various in vitro and in vivo assays and its therapeutic efficacy in animals models of obesity/metabolic syndrome and type-2 diabetes has been well-documented. ${ }^{9,15,16}$ The compound is highly selective for peripheral $\mathrm{CB}_{1} \mathrm{R}$ and has no off-target effects. JD5037 will soon be submitted for IND approval.

Stable isotope labeled standards provide precise quantitation of new drug molecules and human bio-analytical validation. It was rationalized that ${ }^{2} \mathrm{H}_{8}$-labeling on the $\mathrm{L}$-valinamide pendant of the molecule would provide such a useful standard for JD5037 quantitation. Toward that end, a viable procedure was developed, based on the reported synthesis of JD5037, starting from L-valinamide- $\mathrm{d}_{8} 9$ and intermediate $\mathbf{1 0}$ to $\left[{ }^{2} \mathrm{H}_{8}\right]-\mathrm{JD} 5037(\mathbf{8}) .{ }^{14,} 17$

\section{Results and Discussion}

The initial synthesis involved a two-step procedure to assemble L-valinamide- $\mathrm{d}_{8}(\mathbf{9})$. Treatment of commercially available L-valine- $\mathrm{d}_{8}$ with $\mathrm{SOCl}_{2} / \mathrm{MeOH}$ at $65^{\circ} \mathrm{C}$ followed by condensation with $\mathrm{NH}_{4} \mathrm{OH} / \mathrm{MeOH}$ at $65^{\circ} \mathrm{C}$ afforded L-valinamide- $\mathrm{d}_{8}$. The L-valinamide- $\mathrm{d}_{8}$, was used without further purification. The sulfonyl urea $10^{17}$ was converted into the imidoyl chloride in the presence of $\mathrm{PCl} 5$ and refluxing chlorobenzene. After evaporation of the chlorobenzene, the chloroimidate $\mathbf{1 1}$ was treated in situ with a mixture of L-valinamide-d8 and triethylamine in methanolic dichloromethane to yield a mixture of diastereomers $\mathbf{1 2}$ (Scheme 1). Flash chromatography purification followed by a recrystallization of the mixture in ethanol yielded $\left[{ }^{2} \mathrm{H}_{8}\right]$-JD5037 with about 80-90\% diastereomeric purity. Additional re-crystallization of this enriched mixture in ethanol-dichloromethane mixture (1:1) yielded $\left[{ }^{2} \mathrm{H}_{8}\right]$-JD5037 (8) as white crystalline needles with undetectable amounts of compound 13. The mother liquor was then subjected to further purification under 
chromatography conditions to give the diastereomer of $\left[{ }^{2} \mathrm{H}_{8}\right]$-JD5037 (13). The X-ray crystal structure of the deuterium-labeled compound 8 confirmed the $(S, S)$ stereochemistry as seen in Figure 3.

The identity of the active diastereomer $8\left(\left[{ }^{2} \mathrm{H}_{8}\right]-J D 5037\right)$ was further corroborated by $\mathrm{CB}_{1} \mathrm{R}$ radioligand binding studies as illustrated in Figure 4/Table 1.

\section{Conclusions}

L-Valine- $\mathrm{d}_{8}$ ( $\geq 98$ atom \% D) was used as the stable-isotope label reagent in the labelled synthesis of L-valineamide- $\mathrm{d}_{8}$ intermediate. This approach allowed for the rapid incorporation of the L-valineamide- $\mathrm{d}_{8}$ in the synthesis of deuterium labelled JD5037. The $\left[{ }^{2} \mathrm{H}_{8}\right]-$ JD5037 will be used to quantitate unlabeled JD5037 during clinical ADME studies and will be used as an LC-MS/MS bioanalytical standard. The synthesized compound $\mathbf{8}$ showed isotopic purity of $\geq 98 \%$ and purity of $>99 \%$.

\section{Experimental}

\section{Chemistry}

Reagents available commercially were purchased and used as is. Intermediate compounds were synthesized based on literature procedures. D8-L-valine (98\% D) was purchased from Cambridge Isotope Laboratories or synthesized based on literature procedures. Proton $\left({ }^{1} \mathrm{H}\right.$ NMR) spectra were recorded on a Varian 400 or Bruker $500 \mathrm{MHz}$ spectrometer in $\mathrm{CDCl}_{3}$ or DMSO- $\mathrm{d}_{6}$ (unless otherwise noted) with the values given in ppm (TMS as internal standard) and $J(\mathrm{~Hz})$ assignments of ${ }^{1} \mathrm{H}$ resonance coupling. Mass spectra (HRMS) were recorded on a VG 7070E spectrometer or a JEOL SX102a mass spectrometer. Thin layer chromatography (TLC) analyses were carried out on Analtech silica gel GHLF $0.25 \mathrm{~mm}$ plates using various gradients of $\mathrm{CHCl}_{3} / \mathrm{MeOH}$ containing $1 \% \mathrm{NH}_{4} \mathrm{OH}$ or gradients of EtOAc: $n$-hexane. Visualization was accomplished under UV light or by staining in an iodine chamber. Flash column chromatography was performed on Teledyne ISCO Combiflash system with PurIon mass detector. Product yields are un-optimized. Compounds tested in radioligand binding assay had $\geq 95 \%$ purity. Purity and structural confirmation was analyzed by a combination of TLC, ${ }^{1} \mathrm{H}-\mathrm{NMR}$, LC/MS, high-resolution mass spec, elemental analysis and X-ray (where indicated). LC-MS detection was carried out on Agilent 1200 using Luna $\mathrm{C}_{18} 3$ um $(3 \times 75$ $\mathrm{mm})$. The mobile phase was $4 \%$ to $100 \%$ acetonitrile ( $0.05 \%$ TFA) standard gradient. The LC-MS chromatogram showed the correct molecular $\left(\mathrm{MH}^{+}\right)$ion as well as a single peak at UV $(254 \mathrm{~nm})$. X-ray results were obtained utilizing the X-ray facility at University of California, San Diego.

\section{2-Amino-3-(methyl- $\left.d_{3}\right)$ butanamide- $d_{5}$ (L-valinamide- $\left.d_{8}\right)(9)$}

To a solution of L-valine- $\mathrm{d}_{8}(125 \mathrm{mg}, 1.00 \mathrm{mmol})$, in methanol at $-20{ }^{\circ} \mathrm{C}$ was added dropwise thionyl chloride $(0.37 \mathrm{~mL}, 5.00 \mathrm{mmol})$. The mixture was heated to $65^{\circ} \mathrm{C}$ overnight, cooled to room temperature and solvent evaporated. The residue was taken up in methanolic ammonium hydroxide $(2.00 \mathrm{~mL})$, heated at $65^{\circ} \mathrm{C}$ for $24 \mathrm{~h}$, and the organic solvent was evaporated to dryness to yield compound 9 . The crude product, $\mathrm{L}$-valinamide- $\mathrm{d}_{8}$, was used as is in the next step. LRMS $\left(\mathrm{MH}^{+}\right)$for $\mathrm{C}_{5} \mathrm{H}_{5} \mathrm{D}_{8} \mathrm{~N}_{2} \mathrm{O}$ 125.1. 


\title{
2-((S)-3-(4-chlorophenyl)- $N^{\prime}$-((4-chlorophenyl)sulfonyl)-4-phenyl-4,5-dihydro-1 H-pyrazole-1- carboximidamido)-3-(methyl- $\left.d_{3}\right)$ butanamide- $\left.d_{5}\left({ }^{2} \mathrm{H}_{8}\right]-\mathrm{JD5037}\right)(8)$
}

\author{
A mixture of compound $\mathbf{1 0}^{17}$ (200 mg, $\left.0.43 \mathrm{mmol}\right)$ and $\mathrm{PCl}_{5},(107 \mathrm{mg}, 0.50 \mathrm{mmol})$ in \\ chlorobenzene $(5 \mathrm{~mL})$ was refluxed for $1 \mathrm{~h}$ to give the imidoyl chloride $\mathbf{1 1}$. The reaction \\ mixture was then cooled and chlorobenzene was removed in vacuo. To the crude imidoyl \\ chloride compound (11) dissolved in dichloromethane $(10 \mathrm{~mL})$ was added a mixture of \\ compound 9 from the previous step $(80 \mathrm{mg}, 0.65 \mathrm{mmol})$ in methanol/dichloromethane (1:1) \\ and $\mathrm{Et}_{3} \mathrm{~N}(0.12 \mathrm{~mL}, 0.86 \mathrm{mmol})$ at $0{ }^{\circ} \mathrm{C}$ drop-wise. After maintaining at room temperature \\ overnight, the reaction mixture was extracted into dichloromethane, washed with water and \\ purified by flash chromatography using hexanes: EtOAC (6:4) to afford compound $\mathbf{1 2}$ as a \\ mixture of diastereomers. (150 mg, 61\%). This mixture was dissolved in ethanol and slowly \\ allowed to evaporate overnight to give a crop of crystals which was enriched in one \\ diastereomer (80-90\%). The crystals were filtered and dissolved again in an ethanol- \\ dichloromethane (1:1) mixture, warmed to $40{ }^{\circ} \mathrm{C}$, and slowly allowed to cool overnight. The \\ resulting white needles ( $40 \mathrm{mg} / 17 \%$ overall) were enriched in single diastereomer $\mathbf{8}(>99 \%)$ \\ by HPLC analysis. Thus, $\left[{ }^{2} \mathrm{H}_{8}\right]$-JD5037 was synthesized with an isotopic purity of $\geq 98 \%$ \\ and diastereomeric purity of $>99 \%$. Mother liquors from the crystallization were purified \\ again by flash chromatography hexane: ethylacetate (1:1) to afford isomer 13 (30 mg, 13\%) \\ as white needles (>99\%) by HPLC analysis.
}

\section{Compound 8}

${ }^{1} \mathrm{H}-\mathrm{NMR}\left(400 \mathrm{MHz}, \mathrm{CDCl}_{3}\right): \delta 7.86(\mathrm{~d}, J=8.5 \mathrm{~Hz}, 2 \mathrm{H}), 7.51(\mathrm{~d}, J=8.3 \mathrm{~Hz}, 2 \mathrm{H}), 7.41(\mathrm{~d}, J$ $=8.4 \mathrm{~Hz}, 2 \mathrm{H}), 7.30(\mathrm{t}, J=6.3 \mathrm{~Hz}, 3 \mathrm{H}), 7.25(\mathrm{~d}, J=7.2 \mathrm{~Hz}, 2 \mathrm{H}), 7.11(\mathrm{~d}, J=7.0 \mathrm{~Hz}, 2 \mathrm{H})$, 6.39 (s, 1H), 5.50 (s, 1H), 4.64 (s, 1H), 4.43 (t, $J=11.6 \mathrm{~Hz}, 1 \mathrm{H}) 4.12-4.09(\mathrm{~m}, 1 \mathrm{H})$. LC method: $53 \% \mathrm{CH}_{3} \mathrm{CN}\left(0.1 \%\right.$ TFA) Waters XBridge $\mathrm{C}_{18}$ column $4.6 \times 50 \mathrm{~mm}, 4.824 \mathrm{~min}$ detection at $254 \mathrm{~nm}>99 \%$ purity. LC-MS method: Gradient $4-100 \% \mathrm{CH}_{3} \mathrm{CN}(0.05 \% \mathrm{TFA})$ over 4 mins Luna $\mathrm{C}_{18} 3 \times 75 \mathrm{~mm} \mathrm{MH}^{+} 580$ detection at $254 \mathrm{~nm} \mathrm{100 \%}$. HRMS $\mathrm{C}_{27} \mathrm{H}_{20} \mathrm{D}_{8} \mathrm{Cl}_{2} \mathrm{~N}_{5} \mathrm{O}_{3} \mathrm{~S}\left(\mathrm{MH}^{+}\right)$: Found $\mathrm{m} / \mathrm{z} 580.1785$, calcd 580.1792. Anal. calcd for $\mathrm{C}_{27} \mathrm{H}_{19} \mathrm{D}_{8} \mathrm{Cl}_{2} \mathrm{~N}_{5} \mathrm{O}_{3} \mathrm{~S}$ : C, 55.85; H+D, 4.66; N, 12.06; Found: C, 56.09; H+D, 4.60; N, 12.08 .

\section{X-Ray Crystallographic Analysis of (8)}

Suitable crystals of $\mathbf{8}$ were obtained by re-crystallization of the compound from IPA and water (9:1) by slow evaporation of the solvent. The single crystal X-ray diffraction studies were carried out on a Bruker Kappa APEX-II CCD diffractometer equipped with $\mathrm{Cu} \mathrm{K}_{\mathrm{a}}$ radiation $(\lambda=1.5478)$. A $0.113 \times 0.057 \times 0.011 \mathrm{~mm}$ piece of a colorless plank was mounted on a Cryoloop with Paratone oil. Data were collected in a nitrogen gas stream at 100(2) K using $\phi$ and $\varpi$ scans. Crystal-to-detector distance was $45 \mathrm{~mm}$ using variable exposure time $(2 \mathrm{~s}-5 \mathrm{~s})$ depending on $\theta$ with a scan width of $2.0^{\circ}$. Data collection was $99.4 \%$ complete to $68.00^{\circ}$ in $\theta$. A total of 21118 reflections were collected covering the indices, $-22<=\mathrm{h}<=23$, $-6<=\mathrm{k}<=6,-30<=1<=29.4646$ reflections were found to be symmetry independent, with a $\mathrm{R}_{\text {int }}$ of 0.0357. Indexing and unit cell refinement indicated a $C$-centered, monoclinic lattice. The space group was found to be $C 2$. The data were integrated using the Bruker SAINT software program and scaled using the SADABS software program. Solution by direct methods (SHELXT) produced a complete phasing model consistent with the proposed 
structure. All nonhydrogen atoms were refined anisotropically by full-matrix least-squares (SHELXL-2014). All carbon bonded hydrogen atoms were placed using a riding model. Their positions were constrained relative to their parent atom using the appropriate HFIX command in SHELXL-2014. All other hydrogen atoms (H-bonding) were located in the difference map. Their relative positions were restrained using DFIX commands and their thermals freely refined. The absolute stereochemistry of the molecule was established by anomalous dispersion using the Parson's method with a Flack parameter of 0.027 Atomic coordinates for $\mathbf{8}$ has been deposited with the Cambridge Crystallographic Data Centre (deposition number: 1536796). Copies of the data can be obtained, free of charge, on application to CCDC, 12 Union Road, Cambridge, CB2 1EZ, UK [fax: +44(0)-1223-336033 or e-mail: deposit@ccdc.cam.ac.uk.

\section{Compound 13}

${ }^{1} \mathrm{H}-\mathrm{NMR}\left(400 \mathrm{MHz}, \mathrm{CDCl}_{3}\right): \delta 7.82(\mathrm{~d}, J=8.4 \mathrm{~Hz}, 2 \mathrm{H}), 7.49(\mathrm{~d}, J=8.2 \mathrm{~Hz}, 2 \mathrm{H}), 7.37(\mathrm{~d}, J$ $=8.0 \mathrm{~Hz}, 2 \mathrm{H}), 7.25(\mathrm{td}, J=12.4,7.3 \mathrm{~Hz}, 6 \mathrm{H}), 7.06(\mathrm{~d}, J=7.1 \mathrm{~Hz}, 2 \mathrm{H}), 6.38(\mathrm{~s}, 1 \mathrm{H}), 5.87$ (s, $1 \mathrm{H}), 4.60-4.50$ (m, 2H), 3.92-3.89 (m, 1H). LC-MS method: LC method: $53 \% \mathrm{CH}_{3} \mathrm{CN}$ ( $0.1 \%$ TFA) Waters $\mathrm{XBridge} \mathrm{C}_{18}$ column $4.6 \times 50 \mathrm{~mm}, 4.518$ min detection at $254 \mathrm{~nm}>99 \%$ purity. Gradient $4-100 \% \mathrm{CH}_{3} \mathrm{CN}\left(0.05 \%\right.$ TFA) over 4 mins Luna $\mathrm{C}_{18} 3 \times 75 \mathrm{~mm} \mathrm{MH} 580$ detection at $254 \mathrm{~nm} \mathrm{100 \%}$. HRMS $\mathrm{C}_{27} \mathrm{H}_{20} \mathrm{D}_{8} \mathrm{Cl}_{2} \mathrm{~N}_{5} \mathrm{O}_{3} \mathrm{~S}\left(\mathrm{MH}^{+}\right)$: Found m/z 580.1783, calcd 580.1792. Anal. calcd for $\mathrm{C}_{27} \mathrm{H}_{19} \mathrm{D}_{8} \mathrm{Cl}_{2} \mathrm{~N}_{5} \mathrm{O}_{3} \mathrm{~S}$ : C, 55.85; $\mathrm{H}+\mathrm{D}, 4.66 ; \mathrm{N}, 12.06$; Found: $\mathrm{C}$, $56.09 ; \mathrm{H}+\mathrm{D}, 4.60 ; \mathrm{N}, 12.08$.

\section{Radioligand Binding Studies}

\section{Materials for in vitro assays}

JD5037 was obtained from Jenrin Discovery, LLC. CP-55,940 was obtained from the National Institute of Drug Abuse Drug Supply Program (Research Triangle Park, North Carolina, USA). $\left[{ }^{3} \mathrm{H}\right] \mathrm{CP} 55,940$ was obtained from Perkin-Elmer (Waltham, MA). All other chemicals were from Sigma-Aldrich (St. Louis, MO).

\section{$\mathrm{CB}_{1} R$ Binding assay}

The assay was performed as described previously. ${ }^{18}$

\section{Supplementary Material}

Refer to Web version on PubMed Central for supplementary material.

\section{Acknowledgments}

This work was supported by intramural funds from the National Institute on Alcohol Abuse and Alcoholism (NIAAA) to M.R.I, R.C and G.K. Resources from National Institute on Drug Abuse (NIDA) to M.R.I. is gratefully acknowledged. Thanks are due to Dr. John Lloyd of the Laboratory of Analytical Chemistry, NIDDK for supplying high-resolution mass spectral data. Helpful advice and suggestions from Dr. Kenner C. Rice are acknowledged. Dr. Walter Teague, Dr. Christopher LeClair and Raul Calvo are also acknowledged for helping with the NMR and LCMS data. 


\section{References}

1. Pacher P, Bátkai S, Kunos G. The endocannabinoid system as an emerging target of pharmacotherapy. Pharmacol Rev. 2006; 58(3):389-462. [PubMed: 16968947]

2. Howlett AC, Barth F, Bonner TI, et al. International Union of Pharmacology. XXVII. Classification of cannabinoid receptors. Pharmacol Rev. 2002; 54(2):161-202. [PubMed: 12037135]

3. Rodríguez de Fonseca F, Del Arco I, Bermudez-Silva FJ, Bilbao A, Cippitelli A, Navarro M. The endocannabinoid system: physiology and pharmacology. Alcohol Alcohol. 2005; 40(1):2-14. [PubMed: 15550444]

4. Mackie K. Cannabinoid receptors: where they are and what they do. J Neuroendocrinol. 2008; 20(Suppl 1):10-14. [PubMed: 18426493]

5. Klein TW, Newton CA, Friedman H. Cannabinoids and the immune system. Pain Res Manag. 2001; 6(2):95-101. [PubMed: 11854771]

6. Black SC. Cannabinoid receptor antagonists and obesity. Curr Opin Investig Drugs. 2004; 5(4):389394.

7. Janero DR, Makriyannis A. Cannabinoid receptor antagonists: pharmacological opportunities, clinical experience, and translational prognosis. Expert Opin Emerg Drugs. 2009; 14(1):43-65. [PubMed: 19249987]

8. Ward SJ, Raffa RB. Rimonabant redux and strategies to improve the future outlook of CB1 receptor neutral-antagonist/inverse-agonist therapies. Obesity (Silver Spring). 2011; 19(7):1325-1334. [PubMed: 21475141]

9. Tam J, Cinar R, Liu J, et al. Peripheral cannabinoid-1 receptor inverse agonism reduces obesity by reversing leptin resistance. Cell Metab. 2012; 16(2):167-179. [PubMed: 22841573]

10. Chorvat RJ. Peripherally restricted CB1 receptor blockers. Bioorg Med Chem Lett. 2013; 23(17): 4751-4760. [PubMed: 23902803]

11. Lipinski CA, Lombardo F, Dominy BW, Feeney PJ. Experimental and computational approaches to estimate solubility and permeability in drug discovery and development settings. Adv Drug Deliv Rev. 2001; 46(1-3):3-26. [PubMed: 11259830]

12. Hitchcock SA, Pennington LD. Structure-Brain Exposure Relationships. J Med Chem. 2006; 49(26):7559-7583. [PubMed: 17181137]

13. Klumpers LE, Fridberg M, de Kam ML, et al. Peripheral selectivity of the novel cannabinoid receptor antagonist TM38837 in healthy subjects. Br J Clin Pharmacol. 2013; 76(6):846-857. [PubMed: 23601084]

14. Chorvat RJ, Berbaum J, Seriacki K, McElroy JF. JD-5006 and JD-5037: peripherally restricted (PR) cannabinoid-1 receptor blockers related to SLV-319 (Ibipinabant) as metabolic disorder therapeutics devoid of CNS liabilities. Bioorg Med Chem Lett. 2012; 22(19):6173-6180.

[PubMed: 22959249]

15. Cinar R, Godlewski G, Liu J, et al. Hepatic cannabinoid-1 receptors mediate diet-induced insulin resistance by increasing de novo synthesis of long-chain ceramides. Hepatology. 2014; 59(1):143153. [PubMed: 23832510]

16. Jourdan T, Godlewski G, Cinar R, et al. Activation of the Nlrp3 inflammasome in infiltrating macrophages by endocannabinoids mediates beta cell loss in type 2 diabetes. Nat Med. 2013; 19(9):1132-1140. [PubMed: 23955712]

17. Lange JHM, Coolen HKAC, van Stuivenberg HH, et al. Synthesis, biological properties, and molecular modeling investigations of novel 3,4-diarylpyrazolines as potent and selective $\mathrm{CB}(1)$ cannabinoid receptor antagonists. J Med Chem. 2004; 47(3):627-643. [PubMed: 14736243]

18. Iyer MR, Cinar R, Liu J, et al. Structural Basis of Species-Dependent Differential Affinity of 6Alkoxy-5-Aryl-3-Pyridinecarboxamide Cannabinoid-1 Receptor Antagonists. Mol Pharmacol. 2015; 88(2):238-244. [PubMed: 26013543] 
Iyer et al.<smiles>CC(C)[C@H](N/C(=N/S(=O)(=O)c1ccc(Cl)cc1)N1C[C@@H](c2ccccc2)C(c2ccc(Cl)cc2)=N1)C(N)=O</smiles>

JD5037 (1)

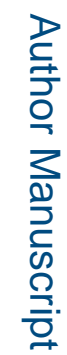

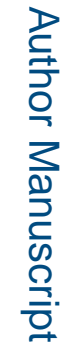

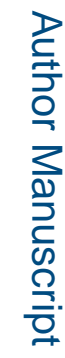

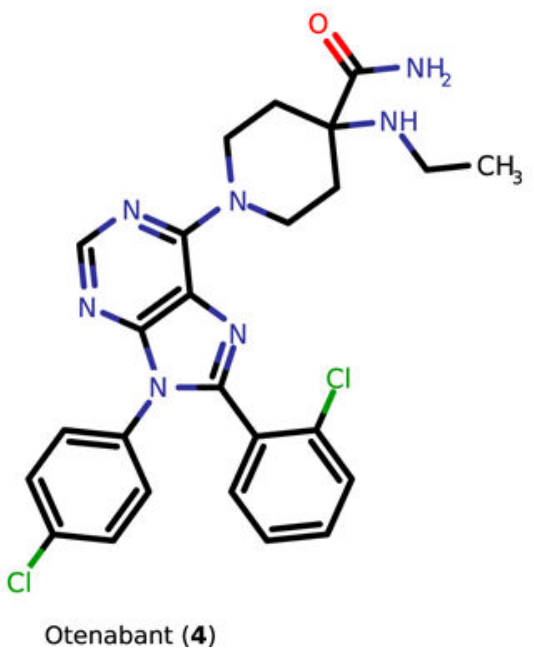

Figure 1.

$\mathrm{CB}_{1} \mathrm{R}$ inverse agonists
Page 8<smiles>Cc1c(C(=O)NN2CCCCC2)nn(-c2ccc(Cl)cc2Cl)c1-c1ccc(Cl)cc1</smiles>

Rimonabant (2)<smiles>C[C@H](NC(=O)C(C)(C)Oc1ccc(C(F)(F)F)cn1)[C@H](Cc1ccc(Cl)cc1)c1cccc(C#N)c1</smiles>

Taranabant (5)

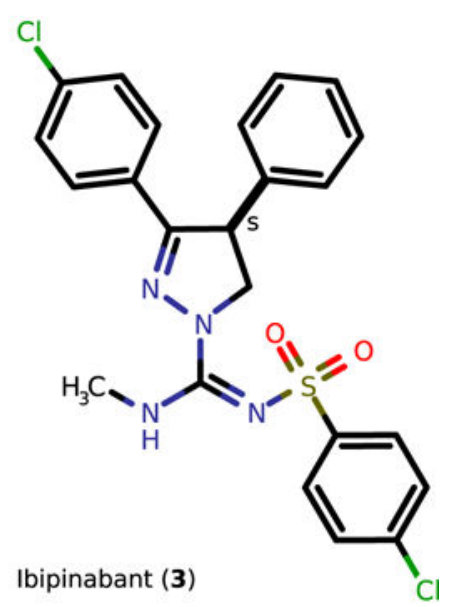

Ibipinabant (3)

J Labelled Comp Radiopharm. Author manuscript; available in PMC 2018 August 02. 
Iyer et al.

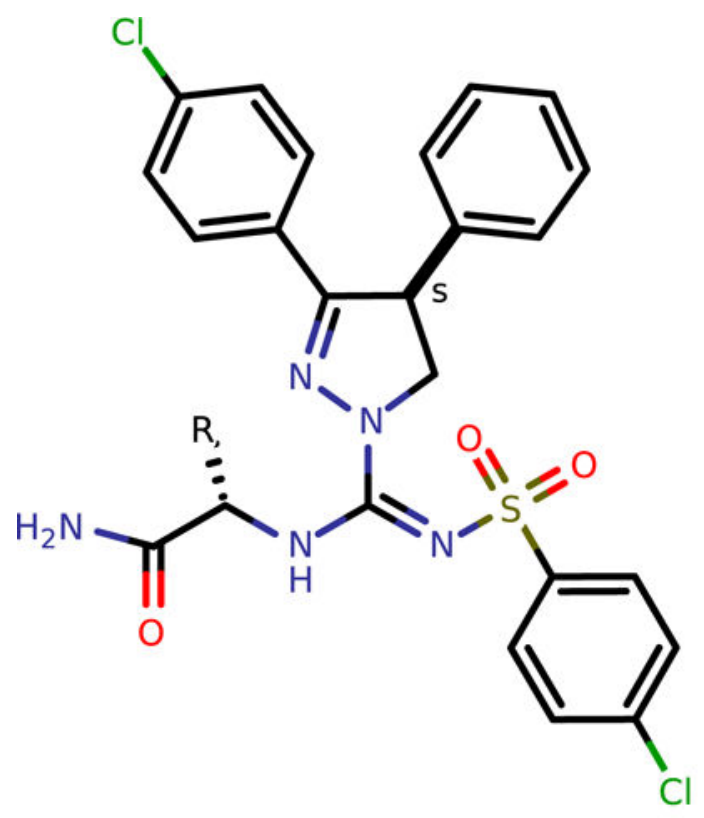

$\mathrm{R}=$ Isopropyl, JD5037 (1)

R - H, JD5006 (7)

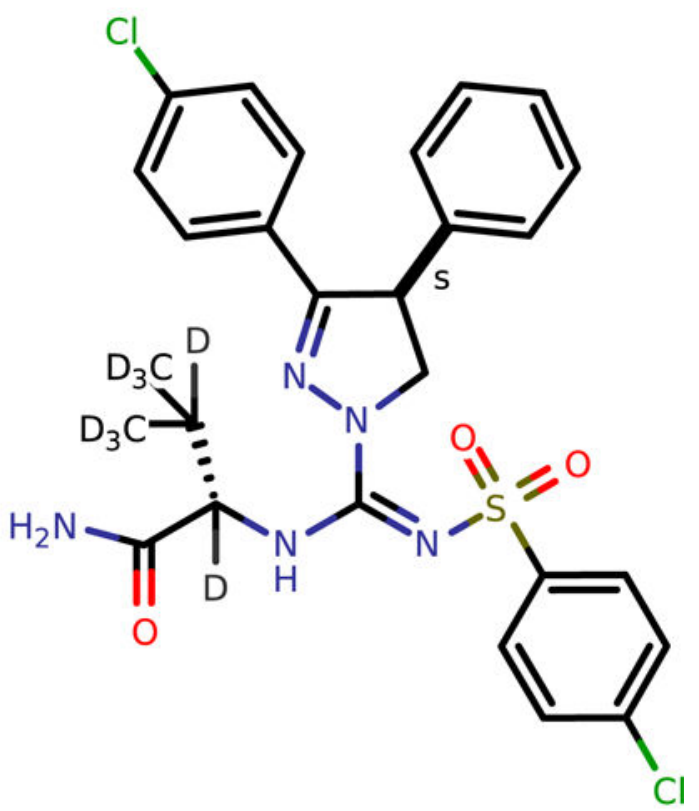

$\left[{ }^{2} \mathrm{H}_{8}\right]-J D 5037(8)$

Figure 2.

Peripherally-restricted $\mathrm{CB}_{1} \mathrm{R}$ inverse agonist JD5037 and its $\mathrm{d}_{8}$ (octa-deuterated) analog 


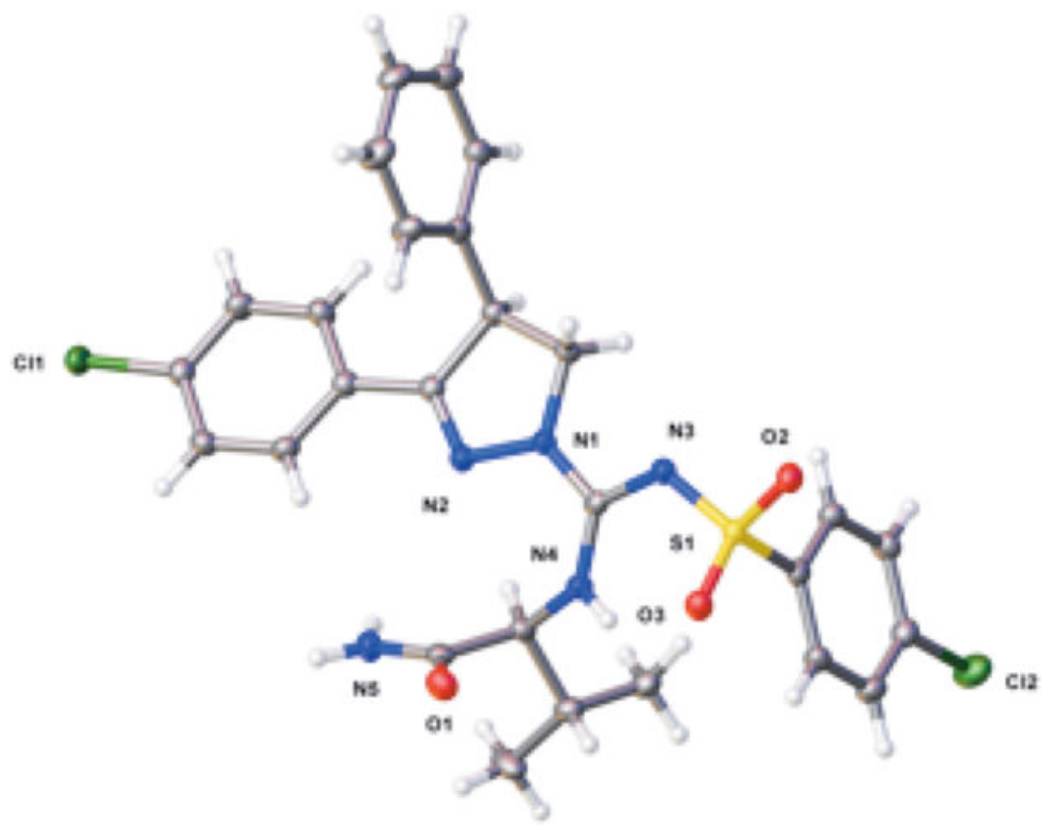

Figure 3.

Single crystal X-Ray structure of Compound $\mathbf{8}$ 


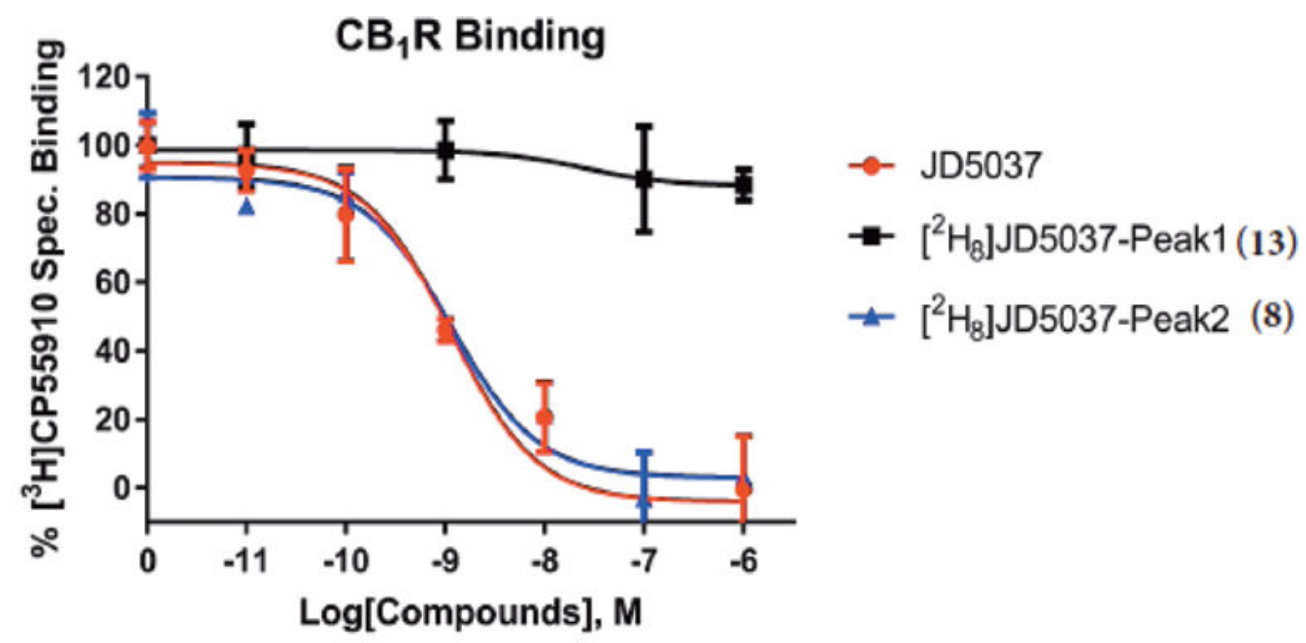

\begin{tabular}{|c|c|c|c|}
\hline & JD5037 (1) & $\begin{array}{c}{\left[{ }^{2} \mathrm{H}_{8}\right] J D 5037-} \\
\text { peak 1 (13) }\end{array}$ & $\begin{array}{c}{\left[{ }^{2} \mathrm{H}_{8}\right] J D 5037-} \\
\text { peak 2 (8) }\end{array}$ \\
\hline $\mathrm{CB}_{1} \mathrm{~K}_{\mathrm{i}}(\mathrm{nM})$ & 0.58 & $>500$ & 0.59 \\
\hline
\end{tabular}

Figure 4.

In vitro $\mathrm{CB}_{1} \mathrm{R}$ binding results of deuterated compounds. Binding affinity was determined from binding displacement isotherms using $\left[{ }^{3} \mathrm{H}\right]-\mathrm{CP} 55940$ as the labeled ligand and plasma membranes from $\mathrm{CB}_{1} \mathrm{R}$-expressing cells. $\mathrm{K}_{\mathrm{i}}$ values were calculated using the Cheng-Prusoff equation. Data represent mean \pm SEM from 3 independent experiments performed in triplicates. 

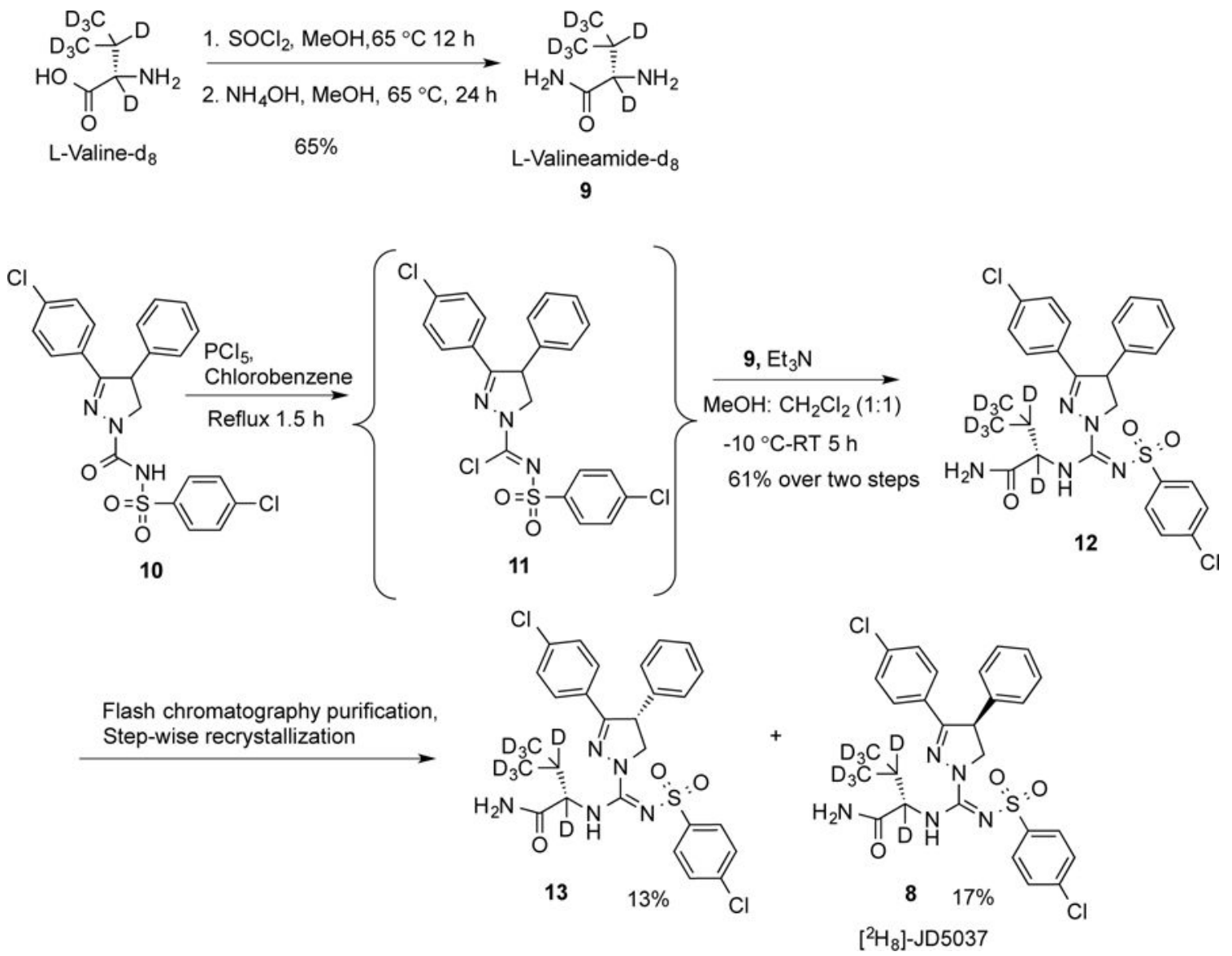

Scheme 1.

Synthesis of $\left[{ }^{2} \mathrm{H}_{8}\right]-J D 5037$ 